\title{
HEILIGING VOLGENS DIE NUWE TESTAMENT
}

\author{
PROF. DR. S. P. J. J. VAN RENSBURG
}

\section{FUNDAMENTELE BETEKENIS VAN HAGIOS}

Vir die verstaan van die grondbetekenis van hagios in die Nuwe Testament moet ons via die Septuagint teruggaan na die hebreeuse teks van die Ou Testament en probeer vasstel wat die grondbetekenis is van qódesh en qãdósh, wat byna deurgaans vertaal word met hagios of één van sy derivate. Ons gaan hier rie in op die moeilike en ingewikkelde diskussies oor die etimologie van qādósh nie, maar stem hier in met Procksch'1) en Fleischer dat die woordgroep (qad, qādad) waarskynlik die betekenis van „skei" verteenwoordig, sodat qadósh die betekenis het van „dit wat geskei is", afgesonder is. Mens kan hier dink aan die gebied wat van die gewone profane lewe geskei, afgesonder is. So kan qãdósh wat ' $n$ suiwer religieuse woord is, waar dit in verband met God gebruik word, in die Ou Testament die afsondering en skeiding aandui waardeur God in sy enigheid onderskei word van alles wat menslik en kreatuurllik is. In die Ou Testament wil qãdósh as attribuut vir God sy alleen-God-wees aandui, sy enigheid, sy heiligheid. Dit wil God onderskei van alles wat kreatuurlik is. Dit wil tot uitdrukking bring dat daar geen wesenskontinuiteit tussen God en skepping bestaan nie. God alleen is God.

\section{HAGIADSEIN EN HAGIASMOS}

Om nou die betekenis van "heiliging" in die Nuwe Testament te kan vasstel, moet ons in die eerste plaas uitgaan van die hagiadsein - en hagiasmos-uitsprake. Die werkwoord hagiadsein is afgelei van die byvoeglike naamwoord hagios, terwyl hagiasmos as Nomen actionis rus op die werkwoord hagiadsein, - -sodat hagiasmos in die eerste plaas nie die betekenis van "heiligheid" as toestand of eienskap verteenwoordig nie, maar „heiliging” beteken as resultaat of effek van die hagiadsein ${ }^{2}$ ).

Aangesien egter die werking van die „heiliging” en van die werkwoord "hagiadsein" slegs van heilige persoon of persone kan uitgaan, is dit ook nodig om te vra wie almal in die Nuwe Testament ,heilig" genoem word, want ook dit sal meehelp om die inhoud en betekenis van die "heiliging" te bepaal. Dit is opmerklik dat die woord hagios 'n wye variasie van toepassinge

1) Vgl. Theologisches Wörterbuch zum Neuen Testament, herausgegeben von Gerhard Kittel - Gehard Friedrich, Bd. I, S. 88.

2) Procksch in ThWb. I, 114, $30 \mathrm{vv}$. 
vind, sodat byvoorbeeld God en Christus en die Heilige Gees „heilig" genoem word, maar dat ook die Christelike gemeente en die gelowiges in die Nuwe Testament baie dikwels hoi hagioi genoem word. Die vraag onstaan of die werking van die hagiadsein en hagiosmos nou ook van al hierdie hagioi uitgaan. Daarom moet ons let op die betekenis en toepassinge wat hagios in die Nuwe Testament het.

\section{WIE WORD NOU ALMAL IN DIE NUWE TESTAMENT „HEILIG" GENOEM?}

In die eerste plaas word God heilig genoem. Die direkte uitsprake oor die heiligheid van God is in die Nuwe Testament betreklik seldsaam. In Joh. 17:11 word Hy aanbid as „heilige Vader". In 1 Petr. 1:15 word Hy genoem die Heilige wat die Christene geroep het. Jesus leer ons om tot God te bid: „Laat U Naam geheilig word" (Matt. 6:9, Luk. 11:2). Dis nie 'n bede dat ons die Naam van God heilig moet maak nie, maar dat God self wat die Heilige is, Homself ook moet betoon en openbaar as die Heilige. Die heiligheid van God beteken in die eerste plaas die alleen-God-wees van God. Sy heiligheid is nie een of ander eienskap of volkomenheid van God naas ander eienskappe of volkomenhede nie. Dis ook nie 'n versamelbegrip van die verskillende volkomenhede van God nie, maar dit dui die geheimsinnige agtergrond, die verborge wesenlike van God aan, wat in al God se volkomenhede aanwesig is as die goddelike daarvan. In hierdie sin is "heillig" sinoniem met ,goddelik". God alléen is God. Hy is die Enige, die „Geheel-Andere”, die Onvergelyklike.

In hierdie sin is ook Jesus Christus „heilig", dit is goddelik, omdat $\mathrm{Hy}$ na sy goddelike natuur van dieselfde wese as die Vader is ${ }^{3}$ ). In dieselfde sin is ook die Heilige Gees "heilig", dit is "goddelik", as die Gees wat van die Vader en die Seun uitgaan.

Maar dan word Christus ook in 'n ander sin, naamlik in heilshistoriese sin "heilig" genoem. Vóor sy vleeswording was Christus reeds heilig soos God die Vader. As daarom in Joh. 10:36 van Christus gesê word dat God Hom geheilig het en in die wêreld gestuur het, dan beteken dit nie dat God dan eers aan Hom die wese van heiligheid meegedeel het nie, maar dat God Hom afgesonder en bestem het vir 'n bepaalde roeping, en Hom daarvoor in die wêreld gestuur het. As volgens Mark. 1:24, Luk. 4:34 die demone uit vrees en ontsetting Christus ho hagios tou theou noem, dan word daarmee uitgespreek dat Jesus, die Messias is, die Heilige van God. wat deur God afgesonder en

3) Vgl. Joh. 17:11; 5:18; 3:31; 1 Joh. 2:20. 
bestem is om die werke van die duiwel te verbreek, die demone te verjaag, om die Satan soos 'n bliksemstraal uit die hemel te laat tuimel (Vgl. Luk. 10:18) en deur die krag van die Heilige Gees die Godsheerskappy op aarde te vestig (Vgl Matt. 12:28; 1 Joh. 3:8). So word ook in Hand. 4:27, 30 Jesus ho hagios pais genoem, die heilige kneg (van God) en in Hand. 4:14 „die Heilige en Regverdige", ho hagios kai dikaios. Want in hierdie benaminge word daar met toespelinge op die Ebed-Jahwe van Jes. 42 en 53 gesê dat Jesus as die heilige kneg as die Heilige en Regverdige (Jes. 53:10) deur God geheilig is, dit is afgesonder en gewy is tot hierdie bepaalde roeping, naamlik om te wees die lydende Kneg van die Here, en die offer vir die sondes van die wêreld.

Niaar dan word dikwels in die Nuwe Testament die gemeente(s) en die gelowiges "heiliges", hoi hagioi genoem. Dit is die oorheersende benaming vir die kerk en die gelowiges in die Nuwe Testament. Dat die Christene „heiliges" genoem is. rus op die belangrike oortuiging dat alle Christene die Heilige Gees ontvang het, en daarom sonder meer ,heiliges" genoem kan word. Maar die heiligheid wat hulle besit is anders as die heiligheid van God. Dieselfde gemeente wat in 1 Kor. 1:2 ,geheiligdes in Christus Jesus, geroepe heiliges" genoem word, is tegelyk 'n gemeente van sondaars, soos dit duidelik blyk uit hierdie eerste brief aan die Korinthiērs.

Maar dit bring meteens die vraag na vore: Hoe kan die Drie-enige God, maar ook onrein sondaar „heilig" genoem word? As Hagios, waar dit van God gebruik word, in die mees-eintlike sin sinoniem met "goddelik" is, hoe kom dit dan dat so baie keer ook mense in die Nuwe Testament heilig genoem word? Word die heiligheid en enigheid van God, van sy goddelikheid hierdeur nie gerelativeer en ingekort nie - deurdat onheilige skepsels ook heilig genoem word? Die antwoord op hierdie vrae is dat daar in die Ou Testament en in die Nuwe Testament 'n radi. kale verskil is tussen die heiligheid van God, en dié van mense. En hierdie antwoord is van direkte belang vir die betekenis van "heiliging" in die Nuwe Testament. Want „heiliging" is nie van toepassing op God nie. Hy is die volmaakte Heilige en het geen heiliging nodig nie. Heiligheid behoort tot sy wese. Hy allén is in absolute sin die Heilige. Sy heiligheid is onder alle omstandghede onvernietigbaar. God alléén is God. Hy is na sy wese die Alleen-Heilige.

Maar die heiligheid van mense is verleende heiligheid. Hulle kan alleen hagioi wees as hēgiasmenoi. Om heilig te wees is heiliging vir hulle onmisbaar. As die Bybel van heilige mense, van "die heilige volk", van „die heilige gemeente" spreek dan is dit steeds met die besef dat netso goed van hulle onheiligheid 
gespreek kan word. Hulle besit geen heiligheid in hulle self nie. Hulle kan alleen heilig genoem word deur dit wat God in sy genade aan hulle gedoen het. God het in sy barmhartigheid hulle verkies en afgesonder as sy volk, sy eiendom en vir sy diens.

4. Wie is dit nou wat heilig maak, wat die hagias volbring? Is die heiliging alleen God se werk of is dit mensewerk, of albei? Moet mensewerk die heiliging verwerklik, aanvul of voltooi? Is heiliging die maeilike weg wat die Christen in eie krag nog self moet gaan? Is die heiliging soos 'n hemelleer wat moeisaam bestyg moet word om tot in die teenwoordigheid van die Heilige te kom, om so self die naam ,heilig” te verwerf? Is die heiliges die vroom enkelinge wat deur eie deug en inspanning bo die onheilige massa uitstyg? Is daar grade van heiligheid? Is daar in die heiligheid ook ruimte vir mensewerk? - Ruimte vir individualistiese, moralistiese of wettiese selfheiliging, ruimte vir menslike heiligheidsoefeninge, vir werkheiligheid? Met hierdie vrae is die probleem in sy verskillende fasette aangedui! Dit is Guidelik dat ' $n$ afwyking van die Bybelse voorstelling van heiliging in teologie en prediking skadelike gevolge vir die geloof en lewe van die Christelike kerk moet hê.

5. Om 'n duidelike oorsig van die uitsprake oor die heiliging in die Nuwe Testament te kry, is dit goed as ons hulle, wat die tydsorde betref volgens vier gesigspunte indeel:

a) Eerstens is daar 'n groep uitsprake waarin daar oor die heiliging van die gemeente in Aoristi en Perfekta gespreek word, as oor iets wat plaasgevind het, en as 'n voldonge feit vasstaan. Hierdie uitsprake sien op die volbragte heiliging deur God of deur Christus. Daar is skrifplase waarin dit duidelik is dat dit God is wat die gemeente as die godsvolk van die Nuwe Testament geheilig het, vgl. 1 Petr. 1:15; 1 Petr. 2:9, 10. Hierin gryp die Nuwe Testament direk terug op die Ou-Testamentiese uitsprake soos Deut. 7:6; Ex. 19:5, 6; Lev. 19:2, waarvolgens dit God self is wat as genadedaad sy hele volk Israel verkies, geroep en geheilig het, afgesonder het uit die volke om sy heilige volk, sy eiendom te wees. So word nou ook die skrifplase in die OuTestament oor die verkiesing, roeping en heiliging van Israel oorgedra en toegepas op die Christelike kerk as die godsvolk van aie Nuwe Verbond. God het deur die offer van Christus die heiliging voltrek aan die gemeente van die Nuwe Verbond. Hierdie uitsprake sien op die volbragte heiliging deur die offer van Christus, wat volgens 1 Kor. 1:30 vir ons geword het ... . hagiasmos. En as in Hand. 20:32, 26:18, 1 Kor. 1:2 en Hebr. 10:10 die Christene in die Perf. passief Participium aangedui word as die hēgiasmenoi, dan is die voorstelling daarin dat dit God is wat 
deur die offerande van Christus vir Hom 'n gemeente reeds afgesonder het, verkry het as sy eiendom om alleen aan Hom te behoort, en vir sy diens. Volgens ander uitsprake is dit Christus self wat deur sy offer sy gemeente geheilig het - Hebr. 10:10. Volgens Ef. 5:25, 26 sê Paulus dat Christus Homself vir sy gemeente oorgegee het om dit te heilig. Hebr. 10:29 spreek van die bloed van die verbond waardeur die Christene geheilig is, Vgl. Openb. 5:9.

b) Tweedens is daar die skrifplaas waarin daar van die heiliging gespreek word as van 'n gebeurtenis wat vir die gelowige reeds plaasgevind het, en hierdie heiliging gesien word in verband met die doop, vgl. 1 Kor. 6:11. Hier word daar na die doop van die Christen verwys as na 'n gebeurtenis wat vir hom reeds plaasgevind het: „Maar julle het julle laat afwas, maar julle is geheilig, maar julle is geregverdig in die Naam van die Here Jesus, en deur die Gees van onse God." Hier word die doop gesien as 'n eenmalige gebeurtenis in die lewe van die Christen. Die Christen se heiliging is vir hom aanvanklik verwerklik toe hy by sy doop in die gemeente ingelyf is, en so deel gekry het aan die heiliging wat aan die gemeente geskied het deur die offer van Christus, vgl. 1 Kor. 6:11, Hebr. 10:29.

c) Derdens word daar gespreek van die heiliging in teenswoordige sin, as van ' $n$ voortgaande heiliging wat nog besig is om sig te voltrek. Hierdie skrifplase sien op die daaglikse verwerkliking van die heiliging in die gemeente en die gelowiges deur die Heilige Gees. As die Pinkstergees het die Heilige Gees in die lewe van die kerk ingegaan om daar te woon en te werk, om die vrugte van die Heilige Gees voort te bring, Gal. 5:22, om die liefde van God in ons harte uit te stort, Rom. 5:5, om die kerk en die gelowiges te versterk en te heilig vir hulle diens en hulle roeping in die wêreld. Die volbragte heiliging deur Christus word deur die Heilige Gees vir die gemeente en die gelowiges verwerklik en toegeëien ,deur tot ons eiendom te maak wat ons in Christus reeds besit." Met ander woorde: die Heilige Gees as die ander Trooster sluit aan by die volbragte lewenswerk van Christus, wat sy gemeente vir Homself geheilig het, afgesonder het as sy eiendom en vir sy diens, - die Heilige Gees sluit aan by hierdie volbragte werk van Christus, om dit in die gemeente en die gelowiges te verwerklik en toe te eien. Dit is wat die Doopformulier bedoel as dit sê dat die Heilige Gees „ons tot lidmate van Christus wil heilig, deur ons tot eiendom te maak wat ons in Christus besit, naamlik die afwassing van ons sonde en die daaglikste vernuwing van ons lewe ..." 
d) Maar die Heilige Gees wat in die gemeente die werkende teenwoordigheid van God en van Christus verteenwoordig, is ook die Voleinder. Daarom is daar ook uitsprake in die Nuwe Testament wat die ,heiliging" as die werk van die Heilige Gees in eskatologiese perspektief laat sien as die voleinding van die heiliging in die ewige lewe. Die Heilige Gees gaan voort met die heiliging ,deur die daaglikse vernuwing van ons lewe, totdat ons eindelik onder die gemeente van die uitverkorenes in die ewige lewe onbevlek gestel sal word". Hier word die heiliging deur die Heilige Gees voleindig en bestendig as die „vir altyd by die Here wees", 1 Thes. $4: 17 \mathrm{c}$, en daarmee ook die afsondering van alles wat onheilig is, Openb. 21:27.

6. 'n Oorsig oor die hagiadsein-uitsprake van die Nuwe Testament kom kortliks hierop neer: Dit is God wat heilig. Hy heilig Homself, sy Naam (Matt. 6:9; Luk. 11:2). Dit is: Hy openbaar Homself as die Heilige. Hy het Christus geheilig, dit is afgesonder en bestem om Hom as Verlosser na die wêreld te stuur, Joh. 10:36. Hy heilig hulle wat aan Christus behoort, Joh. 17:17. Maar dit is ook Christus wat die heiliging volbring. Hy heilig Homself as offer, om daardeur die synes te heilig, Joh. 17:19. As Heilige is Hy ho hagiadsón aan die hagiadsomenoi, Hebr. 2:11. Hierdie heiliging deur Christus is 'n volbragte werk wat afgesluit is en wat vir ewig vasstaan. Dit is éenmaal volbring. Maar ook die Heilige Gees bewerk die heiliging, deur die volbragte heiliging van Christus te verwerklik, in stand te hou en te voleindig. In al die heiligingsuitsprake is dit God of Christus of die Heilige Gees wat heilig, en die gemeente wat geheilig word. Nêrens is daar van selfheiliging deur die heiliges sprake nie. Steeds is God of Christus of die Heilige Gees die Subjek van die aktiewe werkwoord hagiadsein. Daar is in die Nuwe Testament net één uitsondering, naamlik 1 Petr. 3:15, waar die lesers van 1 Petrus as Subjek en „die Here Christus" as Objek van hagiadsein voorkom; maar dáár het die woorde: „Heilig die Here Christus in julle harte" die werkwoord "heilig" die betekenis van: as heilig erken en eerbiedig, Hom in ons harte omring met die gedagtes van huiwering en ontsag, wat Hom as die Heilige toekom. „Heilig" het as werkwoord hier nie die betekenis van "heilig maak" nie. In die Ou Testament staan God enkele kere as Objek van die intensiewe

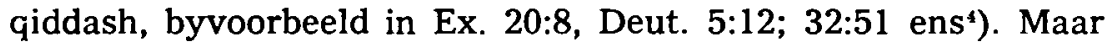
ook hier gaan dit om die erkenning en eerbiediging van wie en wat reeds heilig is, en nie om „heilig maak" nie.

4) Deut. 32:51: „.. . omdat julle My nie geheilig het onder die kinders van Israel nie". 
7. Die gedagte van selfheiliging van die mens moet dus afgewys word, want dit staan in skerp teenstelling teen die NieuTestamentiese heiliging as genadedaad van God aan sy hele gemeente, waardeur Hy sondaars geheilig het, afgesonder het as sy eiendom, en die goddelose geregverdig het, Rom. 4:5. Wie sigself wil heilig, wie sy eie geregtigheid wil oprig, maak hom skuldig aan die houding wat Paulus in Rom. 10:3 beskrywe as die cormoed van die mense wat die geregtigheid en die heiliging as genadegeskenk van God nie dankbaar wil aanvaar nie. Ons vind hierdie houding die suiwerste by die Fariseërs aan die begin van ons jaartelling. Hulle was 'n geslote gemeenskap van eksklusiewe vromes wat op grond van wettiese selfheiliging hulleself skerp afgegrens het van die ām hā-āres, die vervloekte massa wat die wet nie ken nie, Joh. 7:49. Die Fariseërs wil ook die heilige gemeente oprig, maar hulle doen dit deur hulleself te heilig, hulleself af te sonder. Hulle het hulleself die perúshim, die afgesonderdes genoem. In die Midrashim word qadosh en pärush as sinonieme gebruik $\left.{ }^{5}\right)$. Hulle het hulleself as die ware gemeente van Israel, as die heilige godsvolk beskou. Hierdie aanspraak het hulle wetties gefundeer; dit berus op hulle eie werk, troue wetsvervulling, selfheiliging. Dis baie betekenisvol dat die Christelike gemeente nie aangesluit het hy die farisese ideaal van die sigselfheiligende gemeente nie, maar soos dit blyk uit 1 Petr. 1:15; 2:9, 10 , direk teruggegaan het op die oudste beloftes aan die godsvolk van die ou Verbond wat deur God self as hele volk verkies is, afgesonder en geheilig is, soos dit meegedeel word in Ex. 19:5; Lev. 19:2 en Deut. 7:6, 7. So spreek God in Lev. 19:2: Spreek met die hele vergadering van die kinders van Israel, en sê vir hulle: Heilig moet julle wees, want Ek die Here julle God is heilig.

\section{INDIVIDUELE SELFHEILIGING?}

Die voorstelling van selfheiliging wat vreemd is aan die Nuwe Testament bring ons by 'n ander dwaling, naamlik van individuele heiliging, dit is die heiliging van individue los van die gemeenskap van die kerk. Want die gedagte van selfheiliging laat die gedagte van die heiliging van die hele godsvolk los, en maak die heiliging afhanklik van die werk van individue, afhanklik van die verdienstes van vromes. Hierdeur word die heiliging wat ' $n$ suiwer religieuse begrip is, vervlak tot 'n moralistiese begrip. In hierdie sin word "heiliging" nêrens in die Nuwe Testament geleer nie. Die Nuwe Testament ken nie so rets as die

5) Vgl. O. Michel, Der Brief an die Römer, S. 28 oor Aphórismenos in Rom. 1:1. 
heiliging van vroom enkelinge los van die gemeenskap van die kerk nie. Dis opmerklik dat die Nuwe Testament so weinig die gelowiges as vroom eenlinge ken, dat die benaming hagioi vir die kerk en die gelowiges steeds in die meervoud voorkom. Die enigste teks waar hagios in hierdie sin in die enkelvoud voorkom raamlik Filip. 4:21, het dit ook meervoudige betekenis: Groet elke heilige in Christus Jesus, dit is almal van hulle. So word byvoorbeeld in 1 Petr. 2:5, 9 v. in aansluiting by uitsprake soos Ex. 19:5; Lev. 19:2 v., Deut. 7:6, 7 en in Hosea die Nieu-Testamentiese gemeente genoem: 'n ,uitverkore volk", 'n uitverkore geslag, 'n heilige volk tot eiendom verkry. Daar is in die Nuwe Testament geen spoor van 'n opvatting dat die heiliges gesien word as ' $n$ versameling van individuele heiliges wat geleidelik saamgevoeg is tot heilige gemeente, en heilige gemeentes tot die heilige algemene kerk nie. Die verhouding is veeleer omgekeerd: In die heiliging van die hele volk as genadedaad van God is die heiliging van gemeentes en van al die lede reeds ingesluit.

\section{AFDWALINGE:}

As ons nou vashou aan die heiliging van die kerk as geheel, en dit wel as genadewerk van God deur Christus tot stand gebring het, en wat Hy deur die Heilige Gees aan die kerk en aan die gelowiges verwerklik en voleindig, dan is ons in staat om verskillende dwalinge af te wys.

a) Soos dit reeds uit die voorgaande geblyk het, moet alle vorme van individualistiese, wettiese en moralistiese selfheiliging afgewys word, - omdat daardeur die heiliging van die gemeente as genadewerk van God losgelaat word en die eiegeregtigheid opgerig word, volgens een of ander norm van menslike vroomheid of verdienste of deug. Hierdie dwaling bring ons by die Farisese selfheiliging, selfafsondering van die vromes weg van die onheilige res.

Hierdie selfafsondering kom dikwels voor by sektaries-seperatistiese „heiligingsgemeenskappe", ${ }^{6}$ ) wat hulleself vorm tot gemeenskappe en eksklusiewe vromes. Hoe vreemd dit klink, ook die R.K. Kerk laat die heiliging van die kerk as geheel los, ceur 'n besondere heiligheid aan die clerus toe te ken, asook deur die besondere heiliges te sien as die enkelinge wat deur eie

6) Hierdie term Heiligungsgemeinschaft" is ontleen aan F. C. Arnold wat in sy boek: Gemeinschaft der Heiligen und Heiligungsgemeinschaften", 1909 'n kritiese oorsig gee van al die pogings wat in die kerkgeskiedenis voorgekom het om 'n sigbare organisasie van die communio sanctorum daar te stel. 
deug en goeie werke en vroomheid van onderaf uit die massas van die kerk opgestyg het, om heiliges te word, en uiteindelik die toppunt te bereik langs die weg van kerklike heiligverklaring.

Maar ook onder Protestantse Christene en Methodistiese stempel leef nog dikwels die opvatting van selfheiliging wat vir die gelowige voorgehou word as die moeilike weg wat hy in eie krag nog moet gaan, die trapsgewyse vordering van die enkeling na die volmaking. Die gevolg is dat die heiliging wat Christus vir ons volbring het, nie in dankbaarheid en geloof aanvaar word as die vaste fondament vir die heiliging van ons lewe deur die Heilige Gees nie - en dat deur hierdie dwaling die heerlikheid van die Evangelie verduister word. Hierdie Farisese ywer vir selfheiliging by Christene kan 'n strewe wees om sig van die "genade alleen" vry te maak, en in plaas daarvan te stel die selfheiliging as verdienstelike werk van die mens. As gevolg van hierdie dwaling word meermale die heiliging van die Christen gesien as die moeilike weg wat hy in eie krag nog moet gaan. Die gevolg is dat in plaas van die vreugde van die Christen wat weet dat Hy in Christus geheilig is, en dat hy daarop slegs hoef te antwoord met geloof en gehoorsaamheid en dankbaarheid in plaas hiervan kom daar 'n angstigheid en bedruktheid in die lewenswandel wat die heerlikheid van die Evangelie verduister en die vreugde van die geloof en die ware dankbaarheid onmoontlik maak. Dit lei of tot angstige spanning en wanhoop, of dit voed die Farisese eiegeregtigheid.

b) 'n Verdere dwaling is die opvatting dat daar grade van heiligheid sou wees, heilig of nog nie heilig nie, meer of minder heilig by die lede van die kerk, en gevolglik verskillende groepe van heiliges. So ken byvoorbeeld die R.K. Kerk aan die clerus 'n besondere graad van heiligheid toe, waardeur die heiligheid van die gemeente tot iets minders gedegradeer word. Die eintlik heiliges wat vereer moet word, staan as enkeles bo die massa van gewone lidmate uit.

Die Nuwe Testament ken geen grade van heiligheid by die Christene nie, want die heiligheid van die kerk is nie gegrond op enigiets mensliks nie; alle relatiwiteit is hier uitgesluit, omdat die heiliging van die kerk en van die gelowiges in God rus. Die Christene is hagioi as hēgiasmenoi, deur God geheiligdes. Dat daar geen grade van heiligheid by gelowiges is nie, blyk uit die Nieu-Testamentiese gebruik om ál die gelowiges ",heiliges" te noem, omdat hulle almal die Heilige Gees ontvang het. Daarom besit nie één 'n besondere heiligheid wat 'n ander een nie besit nie.

c) Perfeksionisme: Die opvatting van grade van heiligheid skakel weer in 'n ander dwaling, naamlik die Perfeksionisme. 
Dit is die opvatting dat al die lede van die seperatistiese gemeenskap die heiligheid volkome besit, of, dat enkele heiliges die volkome heiligheid bereik, en wel as vrugte op menslike vroomheid en heiligheidsoefeninge. Die Nuwe Testament bevat geen spoor van verering van heiliges, of dat die volkome heiligheid of volmaaktheid in hierdie lewe bereik kan word nie - en dit wel op grond van menslike heiligheidsoefeninge nie. Dit sien ons onder andere in 1 Kor. 1:2 waar Paulus aan die gemeente van Korinthe skryf as ,aan die geheiligdes in Christus Jesus, die geroepe heiliges", maar hulle tog oor allerhande ergelike sondes streng moet teregwys. Hulle is heilige gemeente, maar tog gemeente van sondaars. In hulleself besit hulle geen heiligheid nie. Hulle is heiliges as geheiligdes, deur wat God in Sy genade aan hulle gedoen het, en hulle heiliging moet daagliks deur die Heilige Gees verwerklik en voleindig word.

d) Maar juis op hierdie stadium moet dan ook die dwaling van geloofsquietisme afgewys word. Dit is die opvatting dat omdat God deur die offer van Christus die heiliging van die gemeente en van die gelowiges, volbring het, en dit op 'n onbedrieglike fondament vasstaan, en omdat God hierdie volbragte heiliging ook deur die Heilige Gees vir die gelowiges verwerklik en voleindig - dat daar dan vir ons niks anders te doen oorbly as om passief en met gevoue hande op die heerlike voleinding te wag nie. Hierdie heiliging wat aan die gelowiges geskied, beteken juis die grootste aktiwiteit; want ons is deur God afgesonder, geheilig, nie alleen vir die heerlikheid nie, maar ook vir die diens van Hom wat ons vir sy diens geheilig het. Die Heilige Gees wat in die kerk en in die gelowiges woon en werk en die heiliging in hierdie lewe verwerklik en wat dit ook sal voleindig, is lewend aanwesig en aktief soos n' dinamiese krag. Hy werk die geloof, die gehoorsaamheid en die dankbaarheid, die lofprysing van God. Die diens waartoe die gemeente geheilig is, is dank vir ervare genade. En dit beteken dat ons sal glo dat ons deur God afgesonder is, geheilig is as sy eiendom en vir sy diens, en tot die volkome heiliging op die dag van ons Here Jesus Christus, 1 Thess. 5:23. Dit beteken dat ons gehoorsaam sal wees aan dit waartoe ons geheilig is, en dat ons dankbaar sal wees vir hierdie onbegryplike barmhartigheid.

Daar is wel 'n aantal skrifplase in die Nuwe Testament waarin daar nadruk gelê word op die doen van die mens, maar dan word tegelyk beklemtoon dat die najaag van die heiliging rus op, en alleen moontlik is deur die volbragte werk van God in Christus. Die doen van die gelowige is sy geloof, sy gehoorsaamheid en sy 
dankbaarheid vir die genadewerk van die goddelike heiliging ${ }^{7}$. Hierdie diens as dank dra dus nie die stempel van verdienstelike werk en werkheiligheid nie, maar dit is die vrugte van die Gees wat opgroei uit die geheiligde gemeente en gelowiges, die vrugte van dankbaarheid, vgl. Gal. 5:22; Rom. 6:22.

10. Ten slotte 'n opmerking oor die verhouding van die heiliging tot die sedelike lewe van die geheiligdes. Meermale word die heiliging in die teologie en die verkondiging gemaak tot 'n moralistise begrip en gesien as taak en ideaal van die vroom mens. Daardeur word die heiliging, wat 'n suiwer religieuse voorstelling is, moralisties vervlak en gerasionaliseer, sodat dit nie tot sy reg kan kom nie. Daarom is die vraag belangrik: Wat is die verhouding tussen die heiliging en die sedelike lewe van die geheiligdes? Word die mens geheilig deur sy sedelike strewe? Ons antwoord is: Die heiliging is die werk wat God aan die kerk verrig het deur Jesus Christus en voortgaande verrig deur die Heilige Gees. Hierdie heiliging as afsondering uit die sonde, afsondering vir God en sy diens, raak die hele lewe van die mens. Dit dra vrugte, ook sedelike vrugte van reinheid, selfbeheersing, geduld, ens., in die lewe van die geheiligdes. Die heiliging word herken aan die gestalte wat dit aan die lewe van die geheiligdes gee; dit word herken aan die vrugte wat dit in die lewe van die gelowiges dra, vgl. Rom. 6:22; Gal. 5:22. Die werk van goddelike heiliging gaan vooraf aan die sedelike vrugte; dit raak die sedelike lewe en vorm dit; maar die heiliging as godsdaad mag nie met hierdie lewensvorm en sedelike vrugte vereenselwig word nie, of daarvan afhanklik gemaak word nie.

A. de Quervain sê met reg in sy werk „Die Heiligung" op bls. 10: „Die Heiligung ist in der heiligen Schrift nie etwas was der Ausführung durch Menschen überlassen wird". En E. Gaugler se in sy werkie „Die Heiligung im Zeugnis der Schrift” op bls. 76: „Es müsste doch wohl nicht nur für den gesetzlich angestrengten Einzelgänger irgendeiner Heiligungsbewegung, sondern auch für den Menschen der nichts anderes sein will als ein Glied der Kirche, eine unerhörte Befreiung bedeuten, wenn ihm das Erkenntnis geschenkt würde, dass die Heiligung dies ist, nicht seine krampfhafte Fortschritte in der eigenen Heiligung, - dass si€ nichts anderes sein kann als die Verwirklichung seines Kirche - Seins".

ə) Vgl. Ef. 2:8-10: „Uit genade is julle gered ... geskape tot goeie werke,

Filip. 2:12, 13: Werk julle eie saligheid uit . . . want dit is God wat in julle werk . . . ; Filip. 3:12: Nie dat ek dit al verkry het nie, maar ek jaag daarna of ek dit ook kan gryp - omdat ek ook deur Christus Jesus gegryp is. Telkens rus die Imperatief van God, aan die mens gerig, op die Indikatief van wat God reeds gedoen het. 